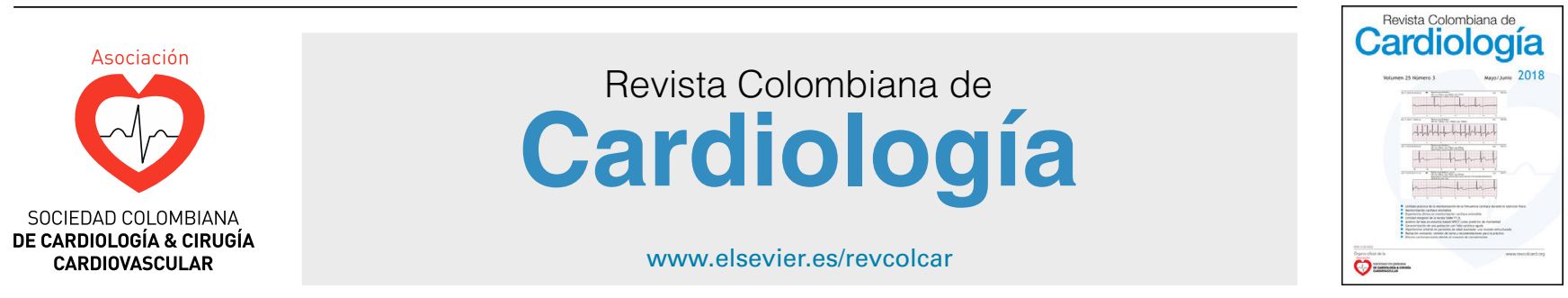

CARDIOLOGÍA DEL ADULTO - ARTÍCULO ORIGINAL

\title{
Complications related to cardiac implantable electronic devices
}

\section{Diego Ignacio Vanegas-Cadavid ${ }^{a, b, *}$, Linda Ibatá-Bernal ${ }^{\mathrm{b}}$, Paula Andrea Franco-Garrido ${ }^{\mathrm{b}}$, Zulma Valderrama-Barbosa ${ }^{\mathrm{a}, \mathrm{b}}$}

\author{
a Electrophysiology Department, Hospital Militar Central, Bogotá, Colombia \\ ${ }^{\mathrm{b}}$ Fundarritmia-Fundación Cardiovascular, Bogotá, Colombia
}

Received 30 October 2018; accepted 12 February 2019

Available online 2 August 2019

\author{
KEYWORDS \\ Complications; \\ Risk factor; \\ Pacemaker; \\ Cardioverter- \\ defibrillator; \\ Cardiac \\ resynchronization \\ therapy; \\ Colombia
}

\begin{abstract}
Introduction: complications due to cardiac implantable electronic devices have been sparsely studied despite the increased number and complexity of these procedures in a population with multiple comorbidities.

Objective: to determine the complication rate and associated risk factors at a reference center in Colombia.

Methods: retrospective cohort study, which included patients who had a cardiac electronic device implanted between 2012 and 2015. Clinical records were reviewed to determine if patients developed complications during the year after the procedure, and, if so, which type and which clinical variables could be related to.

Results: a total of 897 patients were included, 620 with pacemaker implants and 277 with other devices. The average age was 71.4 years, $63.9 \%$ were men, almost all the patients had a chronic disease, and $70 \%$ were de novo implants. The global complication rate was $10.9 \%$; Lead displacement $(3.6 \%)$ and pocket hematoma $(3.3 \%)$ were the most frequent complications; 7.5\% were major complications, and $73.5 \%$ occurred in the first month after procedure. The hospitalization rate associated with complications was $9.5 \%$, and the median hospital stay was seven days, with $66.3 \%$ of these patients requiring new interventions. The mortality rate was $0.2 \%$

Conclusions: complications associated with cardiac implantable electronic devices occur red mainly in the first trimester after the initial intervention, were more frequent in patients under 80 years old, increased according to device complexity, and were not related to with the studied comorbidities.

(c) 2019 Sociedad Colombiana de Cardiología y Cirugía Cardiovascular. Published by Elsevier España, S.L.U. This is an open access article under the CC BY-NC-ND license (http:// creativecommons.org/licenses/by-nc-nd/4.0/).
\end{abstract}

\footnotetext{
* Corresponding author at: Corresponding author.

E-mail address: diegovanegascadavid@gmail.com (D.I. Vanegas-Cadavid).
} 


\section{PALABRAS CLAVE \\ Complicaciones; \\ Factor de riesgo; \\ Marcapaso; \\ Cardiodesfibrilador; \\ Terapia de \\ resincronización \\ cardiaca; \\ Colombia}

\section{Complicaciones asociadas al implante de dispositivos cardiacos electrónicos}

\section{Resumen}

Introducción: las complicaciones secundarias al implante de dispositivos cardiacos electrónicos han sido poco estudiadas a pesar del aumento en número y complejidad de estos procedimientos en población con múltiples comorbilidades.

Objetivo: determinar la tasa de complicaciones del implante de dispositivos y los factores de riesgo asociados, en un centro de referencia en Colombia.

Métodos: estudio de cohorte retrospectiva, que incluyó pacientes a quienes se les implantó dispositivo electrónico cardiaco entre 2012 y 2015. Se revisó la historia clínica para determinar si durante un año posterior al procedimiento, presentaron complicaciones, de qué tipo y con qué variables clínicas podría asociarse.

Resultados: se incluyeron 897 pacientes, 620 con implante de marcapaso y 277 otros dispositivos. La edad promedio fue 71.4 años, $63.9 \%$ hombres, con múltiples enfermedades crónicas, $70 \%$ fueron implantes de novo. Se observó una tasa de complicaciones del 10.9\%, la cual varía de acuerdo con el tipo de dispositivo. El desalojo del electrodo (3.6\%) y el hematoma del bolsillo (3.3\%) fueron las complicaciones más frecuentes, 7.5\% fueron complicaciones mayores y $73.5 \%$ se presentaron en el primer mes postoperatorio. La tasa de hospitalización asociada a complicación fue $9.5 \%$, mediana de estancia de 7 días, con un $66.3 \%$ de los pacientes en requerimiento de reintervención. La tasa de mortalidad fue del $0.2 \%$.

Conclusiones: las complicaciones asociadas al implante de dispositivos eléctricos cardiacos se presentaron principalmente en el primer trimestre, fueron más frecuentes en menores de 80 años, aumentaron con la complejidad del dispositivo y no se relacionaron con las comorbilidades estudiadas.

(c) 2019 Sociedad Colombiana de Cardiología y Cirugía Cardiovascular. Publicado por Elsevier España, S.L.U. Este es un artículo Open Access bajo la licencia CC BY-NC-ND (http:// creativecommons.org/licenses/by-nc-nd/4.0/).

\section{Introduction}

Cardiac implantable electronic devices are indicated for the diagnosis, treatment and follow-up of some disorders in the generation and or conduction of cardiac impulses. The implantation of these devices, including pacemakers, cardioverter-defibrillators (ICDs) and cardiac resynchronization therapy (CRT), has shown a tendency to increase over the last few years ${ }^{1}$, not just due to an increased prevalence of cardiovascular diseases secondary to population aging, but also due to wider indications for their use $^{2,3}$.

The management of these patients requires more complex and specialized medical services. Patients having these devices are very diverse: from young and active, to older, sedentary and with multiple comorbidities. The device characteristics, such as having an exhaustible battery, require replacement procedures, thus increasing the number of interventions and the risk of complications.

Within the healthcare system, it is necessary to obtain information regarding the complications related to these procedures, and which factors increase both their short- and long-term incidence, in order to propose strategies to prevent them. Although the use of these devices has increased significantly, there are very few reports in Latin America of complications ${ }^{4}$, and no recent studies have been carried out showing the impact of these even more complex procedures on older and sicker people, which may affect the incidence of complications.
Recent international studies of device complications show that some factors such as low body mass index, female sex, age, the use of anticoagulants and/or corticosteroids, a history of diabetes mellitus or a cerebrovascular event, and the complexity of the surgical procedure, predispose to complications $^{5-9}$.

This study attempts to determine the frequency of complications, the need for hospitalization and the mortality rate following implantation of cardiac devices, along with their predictive factors, in patients treated at a reference center; and compare the findings with those described in the worldwide literature.

\section{Methods}

This retrospective cohort study included all patients who had received cardiac electronic device implantation at a reference center in Colombia, between January 1, 2012 and December 31, 2015. The medical records were reviewed to determine if they had experienced complications within one year after the procedure and, if so, which kind, and which other clinical variables could be associated with their appearance. Complication rates were calculated as the proportion of patients that developed a complication out of the total of patients who underwent implant procedure. It is important to note, that one patient could have more than one complication (for example dehiscence and superficial infection). Major complications were those that placed the patient at significant risk, 
requiring an intervention, procedure, or hospitalization for management ${ }^{12}$, as: death, pneumothorax, hemothorax, infections requiring intravenous antibiotics, extrusion of the device, pocket abscess, lead displacement, pocket hematoma requiring surgical drainage or transfusion, and deep vein thrombosis. Infection was defined as the presence of pain, burning, purulent discharge or swelling through the surgical wound, which can occur early (up to 1 month) or late (more than 1 month) and which may or not appear with systemic involvement or suture dehiscence and/or extrusion of the device. The term "impaired wound closure and healing" includes non-infectious pocket secretion, suture dehiscence (infection-related or not), device extrusion and skin healing problems.

All patients underwent the device implantation by means of selective venography of the subclavian and/or axillary vein. Cephalic dissection was not performed. Axillary or subclavian punctures guided by venography depended on the anatomy visualized, the trajectory, diameter and position of these venous structures. Operators tendency was to access the axillary vein as a priority and less the subclavian vein.

All patients with anticoagulation, underwent "bridge therapy" consisting of transient suspension of warfarin or the new oral anticoagulants (NOAC) three days before device implantation and, pre and post-operative coverage with injectable subcutaneous anticoagulants such as enoxaparin with restart of oral anticoagulants slow and progressive at the third postoperative day according to the follow-up of INR.

Descriptive statistics were performed according to variable type. Either Chi-square or Fisher's test was used to evaluate the relationship between categorical variables, according to the assumptions. For relationships between numerical values, Mann Whitney U or Student's T test were used, according to their distribution. A multivariate logistic regression was performed to identify which of the selected variables could be associated with the outcome (having or not having complications); selection process of the variables to include in the model began with a bivariate analysis of each variable. Any variable having a significant bivariate test at a p-value cut-off point of 0.20 was included. A similar analysis of major complications and hospitalization was made. Statistical significance was accepted as less than 0.05; all data were processed using the SPSS version 24 statistical package.

\section{Results}

A total of 897 patients who had undergone device implantation were included as follows: 620 pacemakers and 277 other devices (ICD, ICD + TRC and TRC). Most of the implants, both pacemakers as well as other devices, were performed in men; $57.6 \%$ and $78 \%$, respectively. The average patient age was 71.4 years, with differences according to the type of implant, those receiving other devices being slightly younger. Eighty percent of patients were hypertensive, 26\% had coronary disease (going up to $39 \%$ in patients receiving other devices), $20 \%$ were diabetics and $6 \%$ had chronic obstructive pulmonary disease (Table 1 ).
With regard to the type of procedure, approximately $70 \%$ were de novo, $26 \%$ were generator exchange and $4 \%$ were lead replacements or upgrades.

The global rate of complications was $10.9 \%$, and the major complications rate was $7.5 \%$. A total of $73.5 \%$ of the complications occurred in the first month after surgery, and only $15.3 \%$ after 90 days. The global complications rate varied according to the type of device: $8.9 \%$ for pacemakers and $15.5 \%$ for other devices ( $p=0.003$ ); similarly, the rate of major complications was $6 \%$ for pacemakers and $10.8 \%$ for other devices $(p=0.010)$. The global hospitalization rate related to complications was $9.5 \%: 7.7 \%$ for pacemakers and $13.4 \%$ for other devices $(p=0.008)$, with a median length of stay of seven days, a minimum of one day and a maximum of 26 days. Sixty-five (65) patients, equivalent to $66.3 \%$ of those with complications, required some type of surgical intervention.

Two deaths occurred during the study evaluation time, equivalent to $0.2 \%$. One of these deaths was related to a pocket hematoma and profuse bleeding which caused hypovolemic shock requiring blood transfusion. Due to the patient's poor cardiovascular reserve, it resulted in cardiogenic shock and multiple organ failure. The second case occurred in a patient with a pocket abscess and a similar previous episode, who suffered cardiorespiratory arrest during anesthesia induction prior to device extraction, resulting in hypoxic-ischemic encephalopathy and death.

The most frequent complications were lead displacement (3.6\%) followed by pocket hematoma (3.3\%). An analysis by device showed that the most frequent complication in patients with pacemakers was pocket hematomas $(2.9 \%)$, followed by lead displacement $(2.4 \%)$. In the group of patients with other devices, the most frequent complication was altered closure of the surgical wound and impaired wound healing $(6.5 \%)$, followed by lead displacement $(6.1 \%)$. In general, there were more complications in the group of patients with other devices, especially complications involving lead displacement, impaired wound closure and healing, and infection (Table 2).

There were no differences in complications rate according to procedure type (new, generator exchange or upgrade) $(p=0.268)$. An analysis of patient's characteristics showed that age was significantly lower in those with complications and those who required hospitalization; there was no association between complications and the comorbidities that were studied. An analysis of major complications showed no association with any of the studied variables (Table 3 ).

Factors related to specific complications were analyzed. There was no association between patient characteristics and lead displacement, hemothorax or pneumothorax and infection. For skin lesions, including healing problems and device extrusion, it was found that the greater the age the lower the probability of developing this complication.

\section{Discussion}

The world population has a sustained tendency to prolong its longevity, the incidence of cardiovascular diseases persisted spite of public health measures aimed at controlling it, and the use of cardiac electronic devices has increased. However, in Latin America, the available information 
Table 1 Characteristics of included patients according to the type of device.

\begin{tabular}{|c|c|c|c|c|c|c|c|}
\hline & \multirow{2}{*}{\multicolumn{2}{|c|}{$\frac{\text { Pacemaker }}{620}$}} & \multirow{2}{*}{\multicolumn{2}{|c|}{$\begin{array}{c}\text { Others } \\
277\end{array}$}} & \multirow{2}{*}{\multicolumn{2}{|c|}{$\begin{array}{c}\text { TOTAL } \\
897\end{array}$}} & \multirow[t]{3}{*}{$\mathrm{p}$ value } \\
\hline & & & & & & & \\
\hline & $\mathrm{n}$ & $\%$ & $\mathrm{n}$ & $\%$ & $\mathrm{n}$ & $\%$ & \\
\hline Sex & & & & & & & $0.000^{*}$ \\
\hline Female & 263 & 42.4 & 61 & 22.0 & 324 & 36.1 & \\
\hline Male & 357 & 57.6 & 216 & 78.0 & 573 & 63.9 & \\
\hline Age & & & & & & & $0.000^{* *}$ \\
\hline Mean (SD) & $73.9(14.8)$ & & $65.7(14.2)$ & & $71.4(15.1)$ & & \\
\hline Median & 77 & & 69 & & 75 & & \\
\hline Range & $7-96$ & & $8-87$ & & $7-96$ & & \\
\hline Ventricular ejection fraction & & & & & & & $0.000^{* *}$ \\
\hline Mean (SD) & $55.8(8.3)$ & & 36.7 (11.9) & & $48.3(13.6)$ & & \\
\hline Median & 60 & & 35 & & 55 & & \\
\hline Range & $14-70$ & & $14-63$ & & $14-70$ & & \\
\hline Arterial hypertension & 486 & 78.4 & 229 & 82.7 & 715 & 79.7 & $0.140^{*}$ \\
\hline Diabetes mellitus & 124 & 20.0 & 52 & 18.8 & 176 & 19.6 & $0.669^{*}$ \\
\hline Chronic kidney disease & 89 & 14.4 & 29 & 10.5 & 118 & 13.2 & $0.178^{*}$ \\
\hline Chronic obstructive pulmonary disease & 46 & 7.4 & 10 & 3.6 & 56 & 6.2 & $0.046^{*}$ \\
\hline Hypothyroidism & 193 & 31.1 & 73 & 26.4 & 266 & 29.7 & $0.182^{*}$ \\
\hline Coronary disease & 125 & 20.2 & 107 & 38.6 & 232 & 25.9 & $0.000^{*}$ \\
\hline Sleep apnea & 19 & 3.1 & 13 & 4.7 & 32 & 3.6 & $0.224^{*}$ \\
\hline Chagas disease & 23 & 3.7 & 18 & 6.5 & 41 & 4.6 & $0.065^{*}$ \\
\hline Cerebrovascular disease & 32 & 5.2 & 9 & 3.2 & 41 & 4.6 & $0.205^{*}$ \\
\hline Heart failure & 56 & 9.0 & 207 & 74.7 & 263 & 29.3 & $0.000^{*}$ \\
\hline Use of antiaggregation & 245 & 39.5 & 128 & 46.2 & 373 & 41.6 & $0.060^{*}$ \\
\hline Use of anticoagulation & 169 & 27.3 & 115 & 41.5 & 284 & 31.7 & $0.000^{*}$ \\
\hline
\end{tabular}

Table 2 Complications according to type of device.

\begin{tabular}{|c|c|c|c|c|c|c|c|}
\hline & \multicolumn{2}{|c|}{$\begin{array}{c}\text { Pacemaker } \\
620\end{array}$} & \multicolumn{2}{|c|}{$\begin{array}{c}\text { Others } \\
277\end{array}$} & \multicolumn{2}{|c|}{$\begin{array}{c}\text { TOTAL } \\
897\end{array}$} & \multirow[t]{2}{*}{$\mathrm{p}$ value } \\
\hline & $\mathrm{n}$ & $\%$ & $\mathrm{n}$ & $\%$ & $\mathrm{n}$ & $\%$ & \\
\hline Type of procedure & & & & & & & $0.000^{*}$ \\
\hline New & 443 & 71.5 & 180 & 65.0 & 623 & 69.5 & \\
\hline Generator exchange & 167 & 26.9 & 67 & 24.2 & 234 & 26.1 & \\
\hline Lead exchange + upgrade & 10 & 1.6 & 30 & 10.8 & 40 & 4.5 & \\
\hline Complication & 55 & 8.9 & 43 & 15.5 & 98 & 10.9 & $0.003^{*}$ \\
\hline Major complication & 37 & 6.0 & 30 & 10.8 & 67 & 7.5 & $0.010^{*}$ \\
\hline Hospitalization & 48 & 7.7 & 37 & 13.4 & 85 & 9.5 & $0.008^{*}$ \\
\hline Reintervention & 39 & 6.2 & 26 & 9.3 & 65 & 7.2 & $0.278^{*}$ \\
\hline Lead displacement or fracture & 15 & 2.4 & 17 & 6.1 & 32 & 3.6 & $0.006^{*}$ \\
\hline Pocket hematoma & 18 & 2.9 & 12 & 4.3 & 30 & 3.3 & $0.271^{*}$ \\
\hline Impaired wound closure and healing & 11 & 1.8 & 18 & 6.5 & 29 & 3.2 & $0.000^{*}$ \\
\hline Hemothorax/Pneumothorax & 13 & 2.1 & 3 & 1.1 & 16 & 1.8 & $0.289^{*}$ \\
\hline Infections & 6 & 1.0 & 10 & 3.6 & 16 & 1.8 & $0.006^{*}$ \\
\hline Deep vein thrombosis & 0 & 0.0 & 1 & 0.4 & 1 & 0.1 & $0.309^{* * *}$ \\
\hline
\end{tabular}

\footnotetext{
* Chi square

** Fisher
}

regarding complications related to the implantation of cardiac devices is scarce. In this study, the incidence of these complications at a reference center in Colombia was determined. The study was carried out in a population belonging to a special healthcare system where the followup of all patients is carried out by the institution where the implantation is performed, which ensures the accuracy of the reported rate of complications. 
Table 3 Multivariate analysis of complications in general, major complications and hospitalization rate.

\begin{tabular}{|c|c|c|c|c|c|c|}
\hline & \multicolumn{2}{|c|}{ Any complication } & \multicolumn{2}{|c|}{ Major complication } & \multicolumn{2}{|c|}{ Hospitalization } \\
\hline & OR $(95 \% \mathrm{Cl})$ & $P$ & OR $(95 \% \mathrm{Cl})$ & $P$ & OR $(95 \% \mathrm{Cl})$ & $P$ \\
\hline \multicolumn{7}{|l|}{ Age } \\
\hline 40 to 59 years & $0.84(0.34-2.07)$ & 0.708 & $1.09(0.35-3.31)$ & 0.882 & $0.77(0.29-1.99)$ & 0.585 \\
\hline 60 to 79 years & $0.46(0.20-1.03)$ & 0.062 & $0.60(0.21-1.66)$ & 0.331 & $0.39(0.16-0.92)$ & 0.033 \\
\hline Over 80 years & $0.33(0.14-0.82)$ & 0.017 & $0.48(0.15-1.43)$ & 0.187 & $0.34(0.13-0.85)$ & 0.022 \\
\hline \multicolumn{7}{|l|}{ Type of procedure } \\
\hline Generator exchange & $1.00(0.60-1.66)$ & 0.984 & & & & \\
\hline Lead exchange or upgrade & $1.87(0.79-4.41)$ & 0.152 & & & & \\
\hline Other devices* & $1.22(0.65-2.27)$ & 0.525 & $1.01(0.49-2.11)$ & 0.962 & $1.17(0.61-2.26)$ & 0.633 \\
\hline Coronary disease & $1.40(0.86-2.28)$ & 0.175 & $1.32(0.75-2.33)$ & 0.326 & $1.54(0.92-2.55)$ & 0.093 \\
\hline Heart failure & $1.230 .67-2.27)$ & 0.490 & $1.88(0.92-3.81)$ & 0.080 & $1.29(0.68-2.64)$ & 0.423 \\
\hline Anticoagulants & & & & & $0.16(0.85-2.22)$ & 0.187 \\
\hline
\end{tabular}

The average age of the study population (71 years) coincides with that reported in other series, such as those carried out in Denmark ${ }^{5}$ (73 years), Holland ${ }^{6}$ (71 years), Japan $^{7}$ (70 years), Spain ${ }^{10}$ (73 years) and Brazil ${ }^{11}$ (68 years). The proportion of patients with comorbidities in our population was greater than that reported by other studies, as follows: arterial hypertension $79.7 \%$ and diabetes mellitus $19.6 \%$, compared with $62.8 \%$ and $15.2 \%$, respectively, in a study conducted in Holland ${ }^{6}$, which, in theory, could predispose to a greater frequency of complications. However, complications rate reported in our study $(10.9 \%)$ coincides with the literature, which ranges from $2.4 \%$ in $\operatorname{Japan}^{7}$ to 28.6\% in Brazil ${ }^{5,6,9-11}$.

Previously in Colombia, in a study by Orjuela et al. in $2006^{4}$, a $3.8 \%$ complications rate had been reported, which is lower than the rate found in this study. This could be due to: 1) loss to follow-up, since the population belonged to a healthcare system which did not guarantee that a patient would return to the same center where the procedure was performed, or 2) differences in the included procedures, because most of the devices were pacemakers, and the number of complex devices was much lower compared with our study.

In the present study, complications were more frequent in the group of patients who received more complex devices (pacemakers $8.9 \%$ vs. others $15.5 \%$ ). This finding is similar to that reported in a prospective, multicenter (72 hospitals) study carried out in the United States, called REPLACE ${ }^{12}$, which included patients who had received a generator exchange or an upgrade. In this study, the complication rate was greater in patients who underwent more complex procedures: $11.4 \%$ in procedures that did not require lead addition and $22.9 \%$ in procedures that did require lead addition or upgrades.

The most frequent complications in the pacemaker implantation group were pocket hematoma and lead displacement, and in those with implantation of other devices, the most frequent complications were impaired healing and lead displacement. These complications were related to device characteristics (size, number and type of leads). Out of all the patients who received implants, 9.5\% required inpatient management of their complications, similar to the rate reported in a study carried out in Brazil $^{11}(10.5 \%)$. It is important to note that, in our setting, patients who could be managed as outpatients are hospitalized, due to the inherent characteristics of our healthcare system.

The proportion of pocket hematoma in our population was $3.3 \%$, being greater in patients with other devices $(4.3 \%)$ than in patients with pacemakers $(2.9 \%)$. This figure is lower than reported in the Brazilian study ${ }^{11}(8 \%)$, but greater than the rates in European studies ${ }^{6}(0.2 \%)$ and in a Japanese study $^{7}(0.4 \%)$. This difference could be due to the fact that, in the Japanese study, the proportion of patients on anticoagulants was $18.4 \%$ and the proportion receiving antiaggregants was $16.6 \%$, compared with $31.7 \%$ and $41.6 \%$, respectively, in our study. All patients on anticoagulants received bridge therapy; that is, transient suspension of warfarin or the novel oral anticoagulants (NOAC) a few days prior to device implantation, and pre- and post-operative coverage with subcutaneous injectable anticoagulants such as enoxaparin.

Recently it has been proposed that devices should be implanted without using bridge therapy, based on the findings of uncontrolled studies, and one recent controlled, blind, randomized and multicenter study (BRUISE CONTROL) $^{13}$, which showed a greater incidence of hematomas in patients in whom bridge strategy had been used $(15.9 \%)$ than those without bridge therapy uninterrupted warfarin- (3.4\%). Despite the fact that all of our patients on anticoagulants received individualized bridge therapy, the rate of hematoma was similar to that reported in the group who did not use this strategy in the BRUISE CONTROL study ${ }^{13}$. This could be due to careful pre-operative planning of this strategy, because of the facultative team dedication and experience, the cautious management of anticoagulation (low molecular weight heparin was restarted 24 hours after surgery at a sub-maximal dose, compared with the BRUISE CONTROL study ${ }^{13}$, where maximal doses were begun 24 hours after surgery), the gradual, not sudden, re-starting of warfarin (it was restarted 48 hours after the procedure, while in the BRUISE CONTROL study ${ }^{13}$ it was restarted in the afternoon following surgery, or the next day), the control of trans-operative hemostasis, the reduction of inflammation with the 
application of local cold compresses and pressure on the wound, and meticulous post-implant assessment including close follow-up of the surgical wound for the first month, and a slightly longer hospital stay. It is worth noting that there were no thromboembolic events in patients on whom bridge therapy described in this study was used.

This information seems to be corroborated by the findings of the BRUISE CONTROL-2 study ${ }^{14}$, where there were no significant differences in the rates of substantial hematomas between the uninterrupted administration of NOACs (apixaban, dabigatran and rivaroxaban) and bridge therapy with low molecular weight heparin. The authors of that study, therefore, recommended that the anticoagulation strategy should be individualized according to patient's risk, as was done in the present study.

Lead displacement was one of the most frequent complications, with a global rate of $3.6 \%$; $2.4 \%$ in pacemakers and $6.1 \%$ in other devices. Compared to what has been reported worldwide, the global rate of lead displacement was very similar to that informed in Brazil ${ }^{11}$ (3.5\%), and greater than reported in $\operatorname{Japan}^{7}(0.4 \%)$ and Denmark $^{5}(2.6 \%)$. In our study, there were seven cases of diaphragmatic stimulation making up 0.7\%, a proportion also stated in Dutch ${ }^{6}$ and Brazilian ${ }^{11}$ studies.

Impaired wound closure and healing, which in our study included non-infectious pocket secretion, suture dehiscence (infection-related or not), device extrusion and skin healing problems, had a $3.2 \%$ overall rate; $1.8 \%$ for pacemakers and $6.5 \%$ for other devices. This was most probably related to the size of the cardioverter-defibrillator and cardiac resynchronization therapy generators.

Global infection rate was $1.8 \%$. Of these, half were superficial infections, and they were more frequent in other devices $(3.6 \%)$ than in pacemakers $(1 \%)$. This rate is similar to that reported in studies from other countries, such as Denmark ${ }^{5}(2 \%)$, Japan $^{7}(1.2 \%)$, Brazil ${ }^{11}(1.7 \%)$ and the United States $^{15}(1.3 \%)$. There were no cases of bacterial endocarditis associated with device implantation in our population, unlike Denmark ${ }^{5}(0.5 \%), \operatorname{Japan}^{7}(0.1 \%)$ and Brazil ${ }^{11}$ $(0.3 \%)$.

The only two deaths observed in this study were secondary to a multiple organic dysfunction in a patient with hematoma and hypoxic ischemic encephalopathy in a patient with pocket infection. These events as a result of

Table 4 Multivariate analysis of specific complications.

\begin{tabular}{|c|c|c|c|c|c|c|c|c|}
\hline & \multicolumn{2}{|c|}{$\begin{array}{c}\text { Lead } \\
\text { displacement } \\
\text { or fracture }\end{array}$} & \multicolumn{2}{|c|}{$\begin{array}{l}\text { Hemothorax } \\
\text { Pneumothorax }\end{array}$} & \multicolumn{2}{|c|}{ Skin lesions } & \multicolumn{2}{|c|}{ Infections } \\
\hline & OR $(95 \% \mathrm{Cl})$ & $P$ & OR $(95 \% \mathrm{Cl})$ & $P$ & OR $(95 \% \mathrm{Cl})$ & $P$ & OR $(95 \% \mathrm{Cl})$ & $P$ \\
\hline Male & & & $\begin{array}{l}0.43 \\
(0.15-1.91)\end{array}$ & 0.106 & $\begin{array}{l}1.54 \\
(0.62-3.80)\end{array}$ & 0.353 & & \\
\hline \multicolumn{9}{|l|}{ Age } \\
\hline 40 to 59 years & $\begin{array}{l}4.50 \\
(0.53-37.65)\end{array}$ & 0.165 & & & $\begin{array}{l}0.24 \\
(0.06-0.95)\end{array}$ & 0.043 & & \\
\hline 60 to 79 years & $\begin{array}{l}1.66 \\
(0.20-12.32)\end{array}$ & 0.631 & & & $\begin{array}{l}0.19 \\
(0.06-0.55)\end{array}$ & 0.002 & & \\
\hline Over 80 years & $\begin{array}{l}0.78 \\
(0.08-7.63)\end{array}$ & 0.833 & & & $\begin{array}{l}0.15 \\
(0.04-0.56)\end{array}$ & 0.005 & & \\
\hline \multicolumn{9}{|l|}{ Type of procedure } \\
\hline $\begin{array}{l}\text { Generator } \\
\text { exchange }\end{array}$ & $\begin{array}{l}0.56 \\
(0.29-1.50)\end{array}$ & 0.252 & $\begin{array}{l}0.20 \\
(0.26-1.59)\end{array}$ & 0.130 & $\begin{array}{l}1.82 \\
(0.79-4.16)\end{array}$ & 0.155 & $\begin{array}{l}2.04 \\
(0.69-5.97)\end{array}$ & 0.193 \\
\hline $\begin{array}{l}\text { Lead exchange or } \\
\text { upgrade }\end{array}$ & $\begin{array}{l}1.09 \\
(0.23-5.11)\end{array}$ & 0.907 & $\begin{array}{l}2.29 \\
(0.49-10.72)\end{array}$ & 0.290 & $\begin{array}{l}2.03 \\
(0.53-7.78)\end{array}$ & 0.298 & $\begin{array}{l}2.41 \\
(0.47-12.28)\end{array}$ & 0.288 \\
\hline Other devices* & $\begin{array}{l}1.03 \\
(0.35-2.97)\end{array}$ & 0.955 & & & $\begin{array}{l}1.75 \\
(0.58-5.30)\end{array}$ & 0.316 & $\begin{array}{l}3.61 \\
(0.94-0.27)\end{array}$ & 0.060 \\
\hline Diabetes mellitus & $\begin{array}{l}0.39 \\
(0.11-1.35)\end{array}$ & 0.142 & & & & & & \\
\hline $\begin{array}{l}\text { Chronic renal } \\
\text { insufficiency }\end{array}$ & & & $\begin{array}{l}1.90 \\
(0.59-6.10)\end{array}$ & 0.277 & & & & \\
\hline Coronary disease & $\begin{array}{l}2.08 \\
(0.96-4.51)\end{array}$ & 0.063 & & & & & & \\
\hline Sleep apnea & $\begin{array}{l}2.68 \\
(0.70-10.15)\end{array}$ & 0.146 & & & & & & \\
\hline Heart failure & $\begin{array}{l}1.84 \\
(0.65-5.20)\end{array}$ & 0.248 & & & $\begin{array}{l}2.25 \\
(0.78-6.41)\end{array}$ & 0.130 & $\begin{array}{l}0.98 \\
(0.27-3.56)\end{array}$ & 0.979 \\
\hline Antiaggregants & & & $\begin{array}{l}0.51 \\
(0.16-1.62)\end{array}$ & 0.256 & & & & \\
\hline
\end{tabular}


the hemodynamic stress imposed by the complications on the patient; together with a low functional reserve related to their underlying pathologies. In both cases bacterial endocarditis was ruled out.

Pneumothorax or hemothorax was documented in $1.8 \%$ of the studied patients, and was greater in those receiving pacemakers. This figure is similar to what was reported in studies in Holland ${ }^{6}$ (2.2\%), Denmark ${ }^{5}$ (1.5\%) and Brazil ${ }^{11}$ (1.4\%).

An evaluation of which patient characteristics could be related to the development of complications showed that patients under 80 years presented a greater rate of complications, regardless of the type of device implanted. This coincides with what was stated in similar studies, where a risk factor for complications was identified as being 20 to 49 years old, and being over 80 years old was a protective factor $^{5,9,11}$. In our study younger patients had a greater proportion of complications especially those related with skin problems ( 6 patients out of 48 patients under 40 years), and most of them needed hospitalization. It is important to note that this study included only 48 patients under 40 years, therefore more studies have to be performed in this population in order to confirm this finding that also have been reported by other authors.

Finally, there was no association between major complications and any of the analyzed variables (Table 3). However, given the retrospective nature of this study, it was not possible to study some specific variables such as body mass index, which, according to the reviewed literature, is one of the main determining factors for the development of complications.

Despite the inherent limitations of the design and its retrospective character, the present study provides information regarding the complications of device implantation in a Latin American context, in a captive population, which facilitates not only patient follow-up, but also data collection; Therefore, its results are considered valid for the study population. Although the incidence of complications found in the present study was similar to the European casuistic, it is possible that the incidence of complications related to these devices in the general Colombian healthcare system could be higher, since the results presented here refer to a captive population with a centralized reference system. Table 4

It is necessary to study the statistics from several medical centers, taking in to account, the timeliness of patient care, the diversity of management strategies for complications, and the dedication of specialized groups in order to obtain more accurate information about this topic.

\section{Conclusion}

The current study gives an approximation of the complications rate for the implantation of cardiac electronic devices in a Latin American context. The main finding of this study is the documentation of an approximately $10.9 \%$ incidence of complications (major and/or minor) related to the implantation of cardiac electronic devices. These complications present mainly within the first three months following implantation, occur more frequently in individuals under the age of 80 , are more related to the implantation of complex devices, and may lead to re-interventions and hospitalizations which increase care costs and the risk of health effects for patients. There was no relationship between complications and chronic diseases such as arterial hypertension, diabetes mellitus, chronic obstructive pulmonary disease, hypothyroidism, and coronary disease, among others.

This findings highlight the importance of carrying out more research to identify the predisposing factors for complications in this specific patient population, in order to propose preventive strategies.

\section{Financing}

This article was financed by Fundarritmia - Fundación Cardiovascular.

\section{Conflicts of interest}

None.

\section{References}

1. Uslan D, Tleyjeh I, Baddour L, Friedman P, Jenkins S, St Sauver J, et al. Temporal trends in permanent pacemaker implantation: a population-based study. Am Heart J. 2008;155:896-903.

2. Hauser R. The growing mismatch between patient longevity and the service life of implantable cardioverter-defibrillators. J Am Coll Cardiol. 2005;45:2022-5.

3. Borleffs C, Wilde A, Cramer M, et al. Clinical implementation of guidelines for cardioverter defibrillator implantation: lost in translation? Neth Heart J. 2007;15:129-32.

4. Orjuela A, Vanegas D, Montenegro J. Experiencia en implante de dispositivos de estimulación cardiaca. Rev Colom Cardiol. 2006;12:438-42.

5. Kirkfeldt R, Johansen J, Nohr E, Jørgensen O, Nielsen J. Complications after cardiac implantable electronic device implantations: an analysis of a complete, nationwide cohort in Denmark. Eur Heart J. 2014;35:1186-94.

6. Udo E, Zuithoff N, Van Hemel N, de Cock C, Hendriks T, Doevendans $\mathrm{P}$, et al. Incidence and predictors of short- and long-term complications in pacemaker therapy: the FOLLOWPACE study. Heart Rhythm. 2012;9:728-35, http://dx.doi.org/10.1016/j.hrthm.2011.12.014. Epub 2011 Dec 17.

7. Shakya S, Matsui H, Fushimi K, Yasunaga H. In-hospital complications after implantation of cardiac implantable electronic devices: Analysis of a national inpatient database in Japan. J Cardiol. 2017; piiS0914-5087:30091-6.

8. Polyzos K, Konstantelias A, Falagas M. Risk factors for cardiac implantable electronic device infection: a systematic review and meta-analysis. Europace. 2015;17:767-77.

9. Lin $\mathrm{Y}$, Hung $\mathrm{S}$, Chen P, Yang $\mathrm{C}$, Wo H, Chang P, et al. Risk factors influencing complications of cardiac implantable electronic device implantation: infection, pneumothorax and heart perforation: a nationwide population-based cohort study. Medicine (Baltimore). 2014;93:e213.

10. Villalba S, Roda J, Quesada A, Palanca V, Zaragoza C, Bataller E, et al. Estudio retrospectivo de pacientes sometidos a implante de marcapasos en cirugía mayor ambulatoria y de corta estancia Seguimiento a largo plazo y análisis de costes. Rev Esp Cardiol. 2004; 57:234-40.

11. Silva K, Albertini C, Crevelari E, Carvalho E, Fiorelli A, Martinelli M Filho, et al. Complications after surgical procedures in 
patients with cardiac implantable electronic devices: results of a prospective registry. Arq Bras Cardiol. 2016;107:245-56.

12. Poole J, Gleva M, Mela T, Chung M, Uslan D, Borge R, et al. Complication rates associated with pacemaker or implantable cardioverter-defibrillator generator replacements and upgrade procedures: Results from the REPLACE registry. Circulation. 2010;122:1553-61.

13. Birnie D, Healey J, Wells G, Verma A, Tang A, Krahn A, et al. Pacemaker or Defibrillator Surgery without Interruption of Anticoagulation. N Engl J Med. 2013;368:2084-93.
14. Birnie D. BRUISE CONTROL-2- A Randomized Controlled Trial of Continued versus Interrupted Novel Oral Anti-coagulant at the time of Device Surgery. Anaheim, California: Presentado en: American Heart Association Scientific Sessions; 2017 [Acceso 25 Ene 2018]. Disponible en: http://www.acc.org/latest-incardiology/clinical-trials/2017/11/10/21/56/bruise-control-2.

15. Uslan D, Gleva M, Warren D, Mela T, Chung M, Gottipaty V, et al. Cardiovascular Implantable Electronic Device Replacement Infections and Prevention: Results from the REPLACE Registry. PACE. 2012;35:81-7. 